\title{
常時微動から求めた建物の伝達関数が風の影響で 見かけ上変化するメカニズムの検討 \\ TRANSFER FUNCTION DEFORMATION MECHANISM DUE TO WIND FORCE EFFECT ON BUILDINGS DURING MICROTREMORS
}

\author{
内藤幸雄 $*$, 石橋敏久** \\ Yukio NAITO and Toshihisa ISHIBASHI
}

\begin{abstract}
System identification using a transfer function obtained from the spectral ratio for buildings during microtremors and with soil-structure interaction has advantages and disadvantages. The advantages are that the vibration modes and dynamic characteristics of the buildings themselves can be obtained under small wind velocity conditions. A disadvantage is that the wind force deforms the spectral ratio. This paper describes a study of this phenomena. Three factors were studied: the existence of upper input forces, simultaneous upper and lower input situation, and relation (dependence or independence) between two input forces. Furthermore, it was explained mathematically that the relative magnitudes of base movements due to the upper and lower input forces control this phenomena.
\end{abstract}

Keywords : microtremor, transfer function, damping factor, wind force 常時微動、伝達関数、減衰定数、風外力

1. はじめに

常時微動から建物の振動特性とくに伝達関数を推定しようとする 場合、地盤・建物相互作用が存在する事、風外力が存在し、この分 布状態の正確な測定が不可能な事、相互作用を含む視野で考えた場 合の自由地表面の地動いわゆるばね外入力に相当する地動を正確に は知り難い事、等の原因が伝達関数の正確な推定を困難にしている。

本論では、構造物主要部や基礎の動きの観測結果から構造物の振 動特性を推定する事に主眼がある。地盤・構造物の特性や入力が与 えられ応答を求める問題の定式化としてはLucoの文献》があるが、 本論はこれと逆方向のアプローチであると言う事ができる。本論の 主眼を明確にするために、検討の対象とする系を図 1 の 2 自由度系 に単純化し、Lucoの定式化にならったブロック線図を作ると図 2 を 得る。図から上部入力 $\mathrm{f}_{\mathrm{s}}$ がない場合すなわち地動入力または基礎加 振の場合には上部構造の応答 $\left.\ddot{x}_{1}+\ddot{x}_{b}+\ddot{y}\right)$ と基礎の応答 $\left(\ddot{x}_{\mathrm{b}}+\ddot{\mathrm{y}}\right)$ から上部 構造物の特性 $\left\{\left(2 h_{1} \omega_{1} s+\omega_{1}^{2}\right) /\left(s^{2}+2 h_{1} \omega s+\omega_{1}^{2}\right)\right\}$ が求まるが、上部質点へ の入力 $\mathrm{f}_{\mathrm{s}}$ が存在ししかも測定不能である場合には、上部構造物の伝 達関数を正確には知り得ない事が分かる。すなわち、(上部質点応答 ／基礎応答）をもって上部構造の伝達関数を求めようとしても、基 礎応答以外のもう一つの入力（上部入力）を無視している事になり
不可能であると言える。一方 $\mathrm{f}_{s}$ が既知の場合には文献2)と同様の方 法により、 $\left(\ddot{x}_{1}+\ddot{x}_{b}+\ddot{y}-f / m_{1}\right)$ と $\left(\ddot{x}_{b}+\ddot{y}-f / m_{1}\right)$ の比から上部構造の特性 が求まる。

以上の事から、下部 (地動) 入力以外に上部入力が存在しこれが 不可知である時相互作用を有する系の上部構造のみの伝達関数を求 める事はできない、と考えればこれ以上の議論はあり得ない訳であ り上記が伝達関数が見かけ上変化するメカニズムのすべてであるが、 本論では上部入力の影響を誤差と見なした場合の許容誤差の観点か ら、すなわち 2 入力がある場合でも応答比をもって近似的に伝達関 数として使おうとの立場から、このメカニズムに関し検討する。具 体的には、メカニズムの構成要素を、上部入力の存在、上部入力と 下部入力の同時存在、両入力の関係（独立か非独立か）に分け、各 要素と現象発生との関連性を検討する。許容誤差・適用限界を定量 的に求める作業は本論以降の検討課題とし、本論では、各要素が 種々の条件にある時にどのような現象が生ずるか、その理由はなに か、と言った点を中心に検討する。

構造物の特性を推定する方法としては応答比から伝達関数を求め

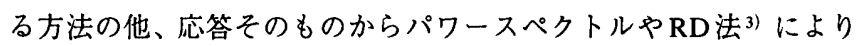
特性を推定する事も行われており、後者の応答そのものから推定す
* 鹿島技術研究所 主管研究員・工博

** 鹿島技術研究所 主任研究員・理修
Chief Research Engineer, Kajima Technical Research Institute, Dr. Eng. Senior Research Engineer, Kajima Technical Research Institute, M. Sci. 


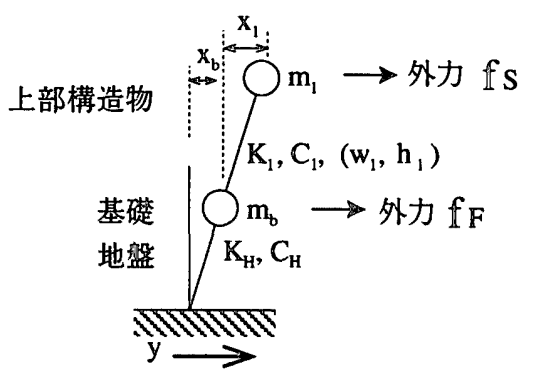

図 1 検討対象を単純化した 2 自由度系

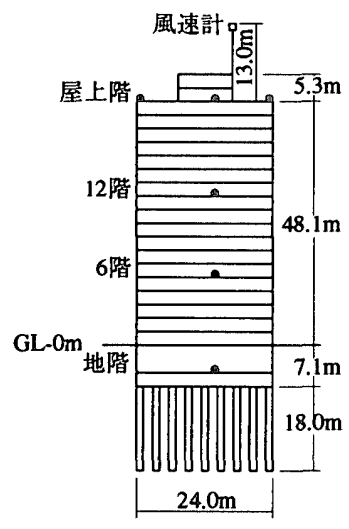

RC 造 18 階建

図 3 測定対象建物 図 5 シミュレーションモデル

る方法からは棬造物一地盤連成形としての特性が求まる。しかしな がら応答比による伝達関数は、1) 上部質点に測定不能な外力 $\mathrm{f}_{\mathrm{s}}$ が 加わらない場合には、構造物一地盤連成系ではなく上部構造のみの 特性が求まる、2) 各点の振幅比のみでなく位相差も得られる事か ら振動モードが求まる、3) 入力がホワイトノイズ的か否かを心配 する必要がない、等の利点を有しており、特性推定のため、できる 限り応答比による伝達関数も用いるべきと考えている。

筆者らは既報4) 6) で、風速の異なる条件下での 18 階建集合住宅 （図 3 ）の常時微動と頂部の風向·風速の観測と分析を行い、1）風 は主に建物の 1 次振動に影響を与える、2) 観測から得られる1次 振動数は風速が変わっても殆ど変化しない、3）頂部応答のパワー スペクトルから得られる減衰定数は風速の影䬸を受けにくいが、伝 達関数 (応答比) からハーフパワー法 $(1 / \sqrt{ } 2)$ 法で得た減衰定 数は風速が大きいとピークの幅が広がるため增大する（図 4)、4） スウェイ・ロッキングばねを持つ質点系モデル（図 5 ) でこれらの 現象が良く再現される、5）二層地盤から成る波動モデル（図 6) でも類似の現象が確認される、等の結論を得た。つまり、風外力に よる応答比の変化としては、ピーク振動数は殆ど変化しないものの 堿衰定数が見かけ上大きくなるようなピーク形状の変化が生ずる事 およびこの現象は数学モデルで説明できる事が分かった、と言える。 従って本論では、特にこの減衰定数の増大に関わるピーク形状の変 化に関し㭘討する。

応答比による伝達関数が風外力の存在により変化する上記の現象 は、前述のように図 2 のブロック線図すなわちシステムが本来持っ ている構造に由来し、そのメカニズムを構成する要素を本論では、 上部入力の存在、上部 · 下部入力の同時存在、両入力間の関係の 3 者に分けた。この分解に基づき、以下の 3 つの状態を想定した解析

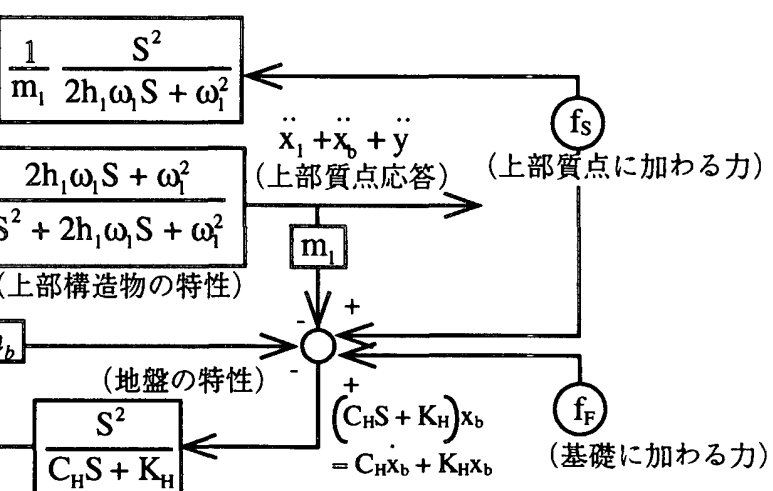

図 2 検討対象の系のブロック線図

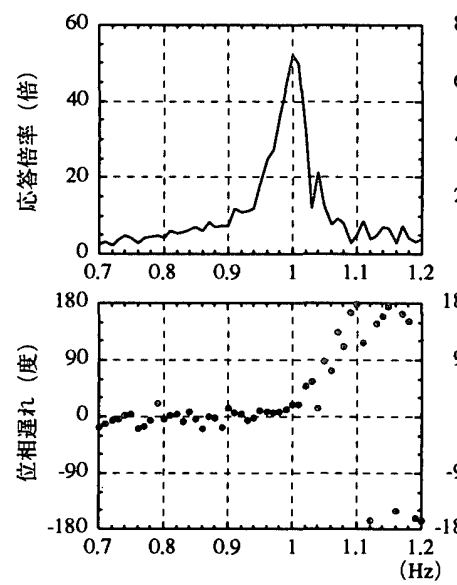

(a) 弱風時（風速 $1.5 \mathrm{~m} / \mathrm{s}$ )

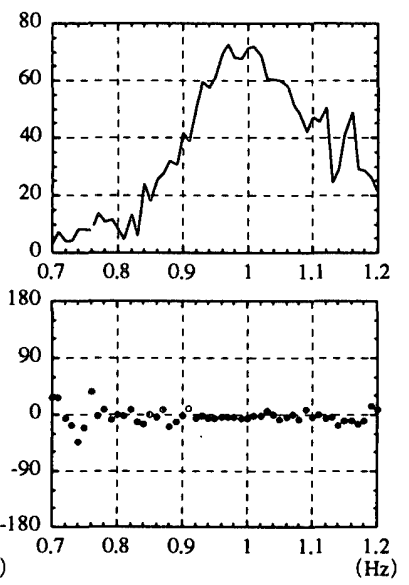

（b）強風時（風速 $13.2 \mathrm{~m} / \mathrm{s}$ )
図 4 実測結果による伝達関数

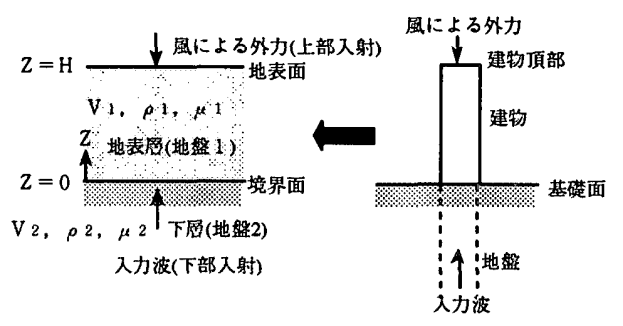

（a） 半無限二層地盤モデル $\quad$ (b) 地盤建物モデル

図 6 建屋 ·地盤系の半無限二層地盤へのモデル化

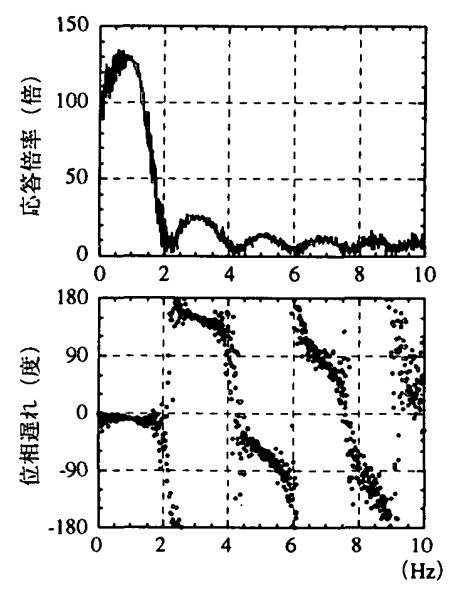

困 7 風外力のみを受ける系の伝達関数 
的検討を行う。

1）地盤・建物相互作用を有す系が上部入力（風外力）を受ける場 合

2 ）上部・下部の 2 入力（風外力と地盤の微振動）を受けこれらが 独立でない場合

3 ）上部・下部の 2 入力（風外力と地盤の微振動）を受けこれらが 独立な場合

\section{2. 上部入カのみが存在する系の応答と伝達関数}

本章では質点系モデルを中心に検討し、また実測やシミュレー ションモデルによる結果を基に高次振動までに関し論ずる。上部入 力としては、風外力の場合と、頂部のみに正弦波入力を受ける場合 を検討する。頂部正弦波は上部入力の極限的形態である。一方風外 力は上部入力ではあるものの、質点間の相関（コヒーレンス・位相 差）が規定されている分布荷重である事から、基礎を含め全質点に 同位相の力が加わる下部入力との中間的な性格も有すると言える。

\section{1 風外カのみを受けるスウェイ・ロッキングばね付多兵点系}

既報4、s)では図 5 に示したスウェイ・ロッキングばねを有する曲 げせん断質点系モデルを用い、また地動加速度と風速の大きさの組 み合わせを種々変化させたシミュレーション解析を行い、実測結果 の現象が良く再現される事を見た。従って本論で検討する現象の要 因は、このモデルに含まれていると考える事ができる。ここでは、 極端な例を解析的に検討し現象の理解を助けるため、風速が大きく
地動加速度による慣性力が相対的に無視し得る場合の極限的なシ ミュレーションの例として、風による外力のみを受ける上記の系の 伝達関数を検討する。

多質点系 ${ }^{4 ）}$ の主な特徵は、1）基礎（7640ton）と上部の19質点 (18 階部分) の総重量（6520ton）がほほ等しい、2）基礎固定時の 1 次共振点は $1.05 \mathrm{~Hz}$ 、減衰定数 $1.0 \%$ 、地盤と杭を考慮したスウエ イ・ロッキングばね付で 1 次共振点 $1.02 \mathrm{~Hz}$ 、減衰定数 $1.4 \%$ である、 等である。この多質点系モデルに、文献 4 ）に示された、各層間の コヒーレンスと位相差を与えられた平均風速 $15 \mathrm{~m} / \mathrm{s}$ 相当の風外力を 加え頂部と基䃈の水平動の比を取り伝達関数（以下、この比を伝達 関数と呼ぶ)を求めたところ、眓 7 の結果を得た。また比較のため、 地動入力のみの場合、同じ $15 \mathrm{~m} / \mathrm{s}$ の風外力および平均風速 $5 \mathrm{~m} / \mathrm{s}$ の風 外力と同時に $0.002 \mathrm{Gal} \mathrm{rms}$ 值の地動加速度を与えられた場合（文献 4 のケース b、ケース $\mathrm{e}$ に相当)、および風速 $3.6 \mathrm{~m} / \mathrm{s} 、 12.5 \mathrm{~m} / \mathrm{s} 、 13.2 \mathrm{~m} / \mathrm{s}$ の 実測結果を図 8 に示した。

風速最大の $13.2 \mathrm{~m} / \mathrm{s}$ の実測結果では約 $3.5 \mathrm{~Hz}$ 以上は $\mathrm{S} / \mathrm{N}$ 比が悪く、 有意な情報を含んでいないと考えられる。この事から、強風時およ び弱風時の、高振動数域の $S / N$ 比の良い代表的なケースとして風速 $12.5 \mathrm{~m} / \mathrm{s}$ （図 $8 . \mathrm{e}$ ）と $3.6 \mathrm{~m} / \mathrm{s}$ （図 $8 . \mathrm{d}$ ）の結果を選んで示した。 これらの結果から以下の事が言える。

風外力のみを受けるモデルの図 7 の結果において、基礎固定時 1 次共振点 $(1.05 \mathrm{~Hz})$ 付近の状態は、図 8 の、強風時の実測(f)や シミュレーション(c)の結果との類似性を有する。即ち振幅のピー
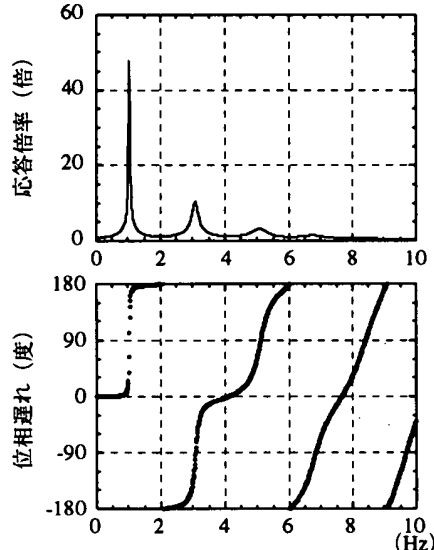

(a) 風外力なし、地動のみ

(1) シミュレーション
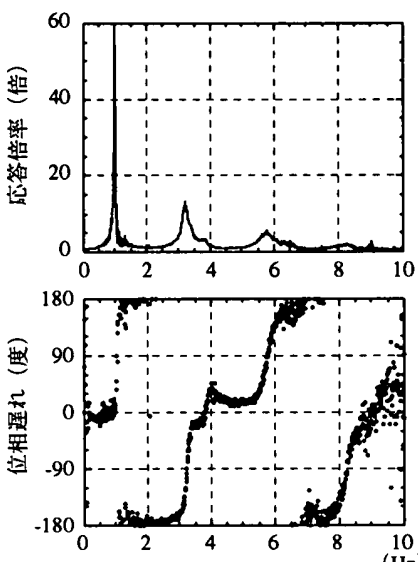

(2) 実测結果
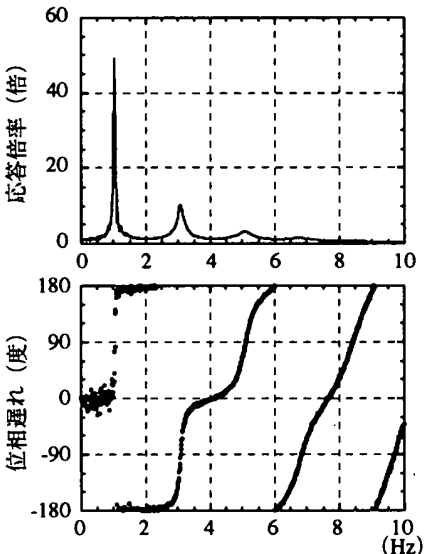

(b) 平均風速 $5 \mathrm{~m} / \mathrm{sec}$ 、地動あり
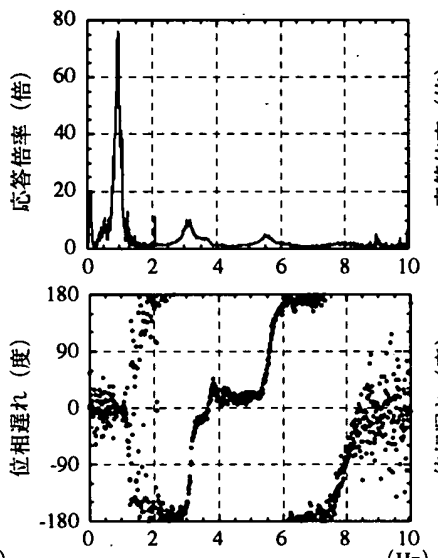

(e) 平均風速 $12.5 \mathrm{~m} / \mathrm{sec}$

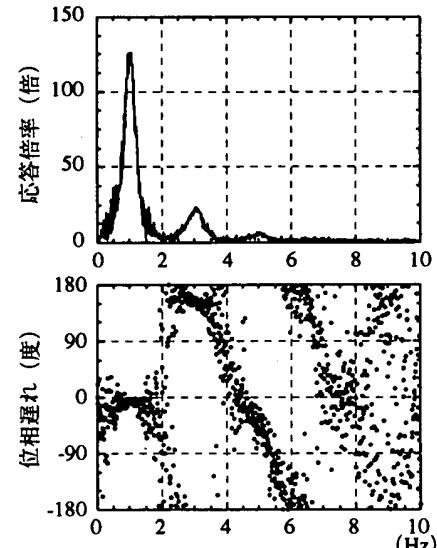

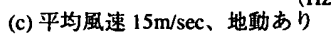
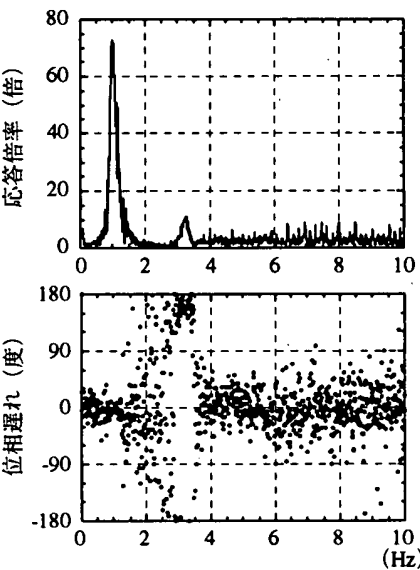

(f) 平均風速 $13.2 \mathrm{~m} / \mathrm{sec}$

図 8 風外力が異なる場合の伝達関数の変化 
頂部 1 tonf 入力

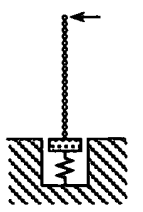

19質点

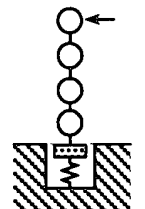

4質点

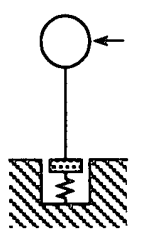

1質点

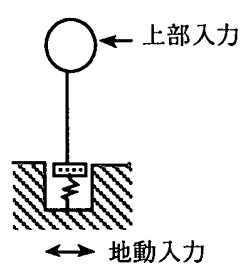

図 112 入力検討用モデル
図 9 上部入力の検討用質点系モデル
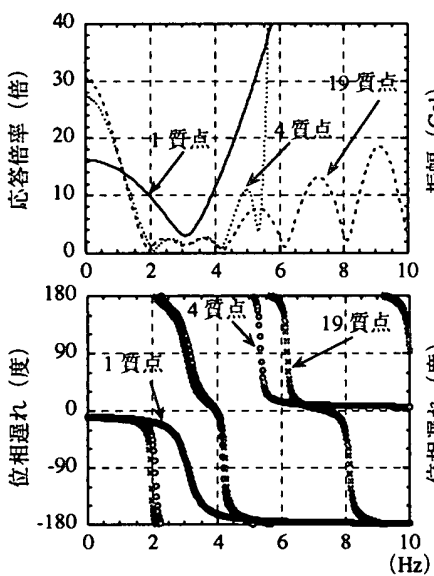

(a) 伝達関数
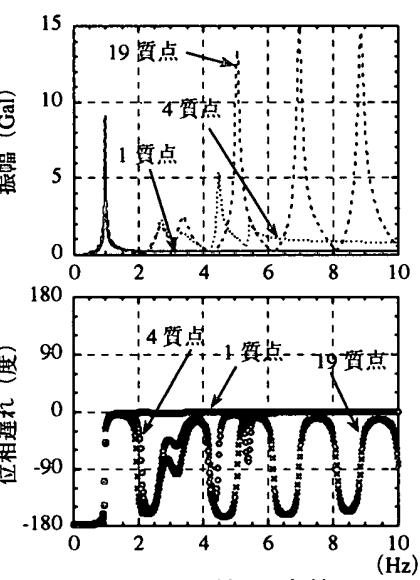

(b) 頂部の応答
図 10 質点系モデル上部正弦波入力の結果

クの広がり方は、風のみのシミュレーション（図 7)、強風時シ ミュレーション（図 8.c )、強風時実測（図 8,f であるが、無風時や弱風時（図 $8 . a, b, d)$ に比較して極め て広がっている点で共通性がある。

位相は、無風・弱風時には $0^{\circ}$ から $180^{\circ}$ （高次では $0^{\circ}$ から $180^{\circ}$ あるいは $-180^{\circ}$ から $0^{\circ}$ ）に変化するのに対し、強風時に は逆に $0^{\circ}$ から $-180^{\circ} 、 180^{\circ}$ から $0^{\circ}$ に変化する点で図 $7 、$ 図 8. c、e、f とも共通性がある。図 7 と図 8，cでは全体にこ の傾向が見られ、図 $8 . \mathrm{f} て ゙ は 4 \mathrm{~Hz}$ 付近まで、また図 $8 . \mathrm{e}$ では $2 \mathrm{~Hz}$ 付近までこの傾向が見られる。さらにこうした強風時あるい は風外力のみによる位相の変化は、無風時や弱風時のような振幅 のピーク付近ではなく、振幅の谷付近で生じている点で、図 7、 図 8，c、e、fに共通性がある。

以上、風外力のみを受ける系の頂部と基礎の応答比から伝達関 数を求めると、強風時の伝達関数と同様にピークの幅が広がりま た振幅の谷で位相が基礎固定時とは逆方向に変化する現象が確認 された。

\section{2 頂部に正弦波入力を受ける系の応答と伝達関数 \\ (1) モデルの概要}

上部入力のもう 1 つの例として、頂部のみに正弦波入力を受ける 系を考え、頂部と基礎の応答比から伝達関数を求める場合を検討す る。これは、上部入力の最も極端な状態を検討する事により、地動 と風外力がある場合の応答比のピーク形状の変化のメカニズム理解 を助けようとするものである。図 9 に示すように、質点系モデルと しては、それぞれ19質点、4 質点、1 質点と基礎から成るせん断系 を考える。以下では、19質点系など、基礎を省略して呼ぶ。これら の系では、水平自由度のみを考應する。基礎重量は、シミュレーショ ンモデル（図 5 ）とほほ同一である。スウェイばねは、文献 7 ）の
表 1 質点系モデルの概要

\begin{tabular}{|c|c|c|c|c|}
\hline & & 19 賈点系 & 4 兵点系 & 1 酶点系 \\
\hline \multirow{3}{*}{ 上部撞造 } & 各筫点重证（ton） & 300 & 1325 & 4735 \\
\hline & 各質点ばね $(\operatorname{tonf} / \mathrm{cm})$ & 1862 & 442 & 191 \\
\hline & 減衰保数ノばね $(\mathrm{sec})$ & 0.0031831 & 0.0031831 & 0.0031831 \\
\hline \multirow{3}{*}{ 基礎 } & 重贵（ton） & 8000 & 8000 & 8000 \\
\hline & 矿ェイばね（tonf $/ \mathrm{cm} ）$ & 2905 & 2905 & 2905 \\
\hline & 堿期係数/ばね $(\mathrm{sec})$ & 0.031831 & 0.031831 & 0.031831 \\
\hline \multirow[t]{2}{*}{1 次 } & 共振振動数 (Hz) & 0.965 & 0.965 & 0.965 \\
\hline & 減衰定数 $(\%)$ & 1.62 & 1.61 & 1.60 \\
\hline
\end{tabular}

考え方に従い、シミュレーションモデルのスウェイ・ロッキングば ねを等価変換して求めた。等分布とした各質点重量は下記(1)式によ ク、4質点系、1 質点系が19質点系と等価になるように定めた。(1) 式は、減衰定数が同じ場合、一次モードによる共振点のベース シャーが同一になるような考えに基づくものである。

$\frac{M}{n}\left(\sum_{r=1}^{n} X_{r 1}\right)^{2} /\left(\sum_{r=1}^{n} x_{r r}^{2}\right)=$ const

$$
\begin{array}{lll}
\text { ここで、 } & \mathrm{M} & \text { : 上部質点総重量 } \\
\mathrm{n} & \text { : 上部質点数 } \\
& \mathrm{X}_{\mathrm{r} 1} & : 1 \text { 次モードの } \mathrm{r} \text { 番目質点の振幅 }
\end{array}
$$

こうして求められた質量に対し、基碟固定時の共振点が振動数 $1 \mathrm{~Hz}$ 、減衰定数が $1 \%$ になるように各層の剛性と減衰を定めた。表 1 にこれらの結果をまとめて示す。なお本論の他の部分の検討では粘 性減衰を用いているが、本 2.2 章では高振動数域の性質も見るため に複淘减衰を用いた。

(2) 伝達関数と応答

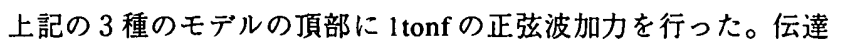
関数を図 10. a に、頂部質点の応答を図 10. b に示す。応答の位相 は、加振力に対する位相遅れを表す。これらから以下が言える。

19質点系の伝達関数は、図 7 の風外力のみの場合や図 8.c、e、 $\mathrm{f}$ の強風時の場合と類似性がある。基礎固定時の 1 次共振点に相 当する $1 \mathrm{~Hz}$ 付近の振幅の様子はピークが広がるのではなく消失し てしまうなど若干異なるものの、振幅の谷が存在する振動数や状 況、 $1 \mathrm{~Hz}$ 付近では位相が 0 に近く、振幅が谷となる振動数におい て主として位相が急変する点などに関しては類似性が強い。

4 質点系と 1 質点系の伝達関数では19質点系と比較し低振動数 域で、図 7 の風外力のみの場合や図 8, c、e、f の強風時の場 合との類似性がある。

頂部の応答（図 10. b ) は伝達関数とは様相が異なる。各モデ ルとも表 1 に示した連成系の 1 次振動数 $(0.965 \mathrm{~Hz})$ で振幅のピー クを示す。

以上、頂部に正弦波加力を受ける上部入力状態で頂部と基礎と の応答比を伝達関数と見なし、図 8.a のような真の伝達関数や 図 7、8の強風時、風外力のみを受ける場合との比較を行った。 その結果、実測・強風時シミュレーション、風外力のみ、頂部正 弦波加力と、現象が次第に極端になったり異なったりする傾向は あるものの、これらを通し一定の傾向が見られた。なお図10の1 質点系伝達関数に関しては、図 14、15に関連し後に再び論ずる。

\section{3 上部入力時の伝達関数の検討結果のまとめ} 以上の検討から下記が言える。 
上部構造に風外力のみが働く場合、頂部に正弦波入力が働く場 合を総合し、地盤・建物相互作用を有する系が上部入力を受ける と、強風時に伝達関数の形状が変化するのと類似の現象が生ずる 事が分かった。

風外力のみが㗢く場合の結果では、振幅と位相の双方の形状に 実測結果との類似がみられた。ピークが広がる振幅の形状の変化 の程度は、風と地動が外力として働く奏測結果と比較し、風外力 のみの解析結果の方が大きい。

頂部に正弦波入力が㗢く場合の結果では、位相は実測結果と類 似であるものの、1 次の振幅の形状に関しては相違がある。しか しながら、無風時に得られる真の伝達関数から大きく変化し鋭い ピークが見られなくなる点では共通性がある。

\section{3. 上部と地動の正弦波入力が存在する系の応答と伝達関数}

第 1 章で示した場合分けに従い、位相差を与えた、すなわち独立 でない正弦波の 2 入力で伝達関数のピークが広がり位相も変化する 現象が再現されるか否かを確認する。また19質点など多質点系モデ ルでは上部入力のみでも伝達関数の形状が変化する現象が再現され るのが前章で確認された事と、単純化のため、以降の検討は図 11 の 1 質点系で行う。モデルの定数は表 1 と同じである。地動は $1 \mathrm{Gal}$, 頂部への加力は 5tonf、10tonf、20tonf、あるいは 50tonf とする。そ の他、入力間の位相差を $5^{\circ}$ づつパラメータとして変化させた。
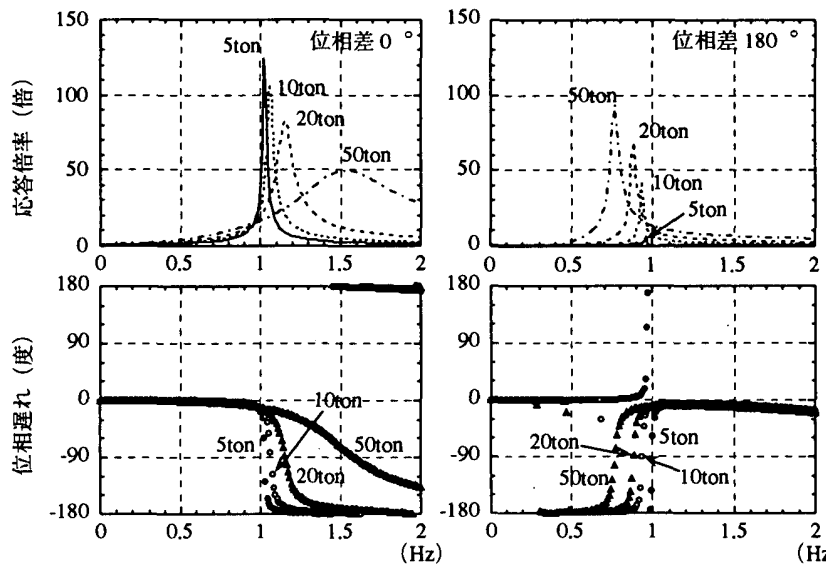

(a) 伝達関数
まず、位相差 $0^{\circ}$ あるいは $180^{\circ}$ で、上部加力が $5 、 10 、 20 、 50$ tonf の場合の結果を図 12 に示した。また上部加力が 20tonf で、位相差 を段階的に $45^{\circ}$ づつ変化させた場合の結果を図 13 に示した。頂部 応答の位相は地動に対する位相遅れである。これらから以下の事が 言える。

伝達関数のピークは振動数、振幅の大きさとも 2 入力により変 化する。振動数の変化は上部入力が大きい程顕著である。位相は 地動入力のみの場合には $0^{\circ}$ から $+180^{\circ}$ に変化するのに対し、こ れと類似の変化の他、 $-180^{\circ}$ 方向への変化や、ピークより低振動 数で一旦 $-180^{\circ}$ 側に変化した後 $0^{\circ}$ 付近にもどる等、複雑な性状 を示す。これらは、2 入力間の位相差により、それぞれの入力に 対する応答にも複雑な位相差が生じた事によると考えられる。

伝達関数の位相に関し、 $0^{\circ}$ から $-180^{\circ}$ 方向への変化が見られ る点は実測結果と共通の傾向である。ただし、実測結果ではピー ク付近より高い振動数で位相が変化するのに対し、ピーク付近で 位相が変化している点が異なる。

実湘結果と似た傾向を示し注目すべき点として、2 久力とな る事により、また上部入力が大きい程ピークが広がる点、 $0^{\circ}$ か ら $-180^{\circ}$ 方向への位相の変化が現れる点、があげられる。

上部質点の応答は、上部入力の大きさによりピークの大きさは 異なるが、ピークの振動数は表 1 に示した連成系の 1 次の振動数 $(0.965 \mathrm{~Hz})$ と一致している。
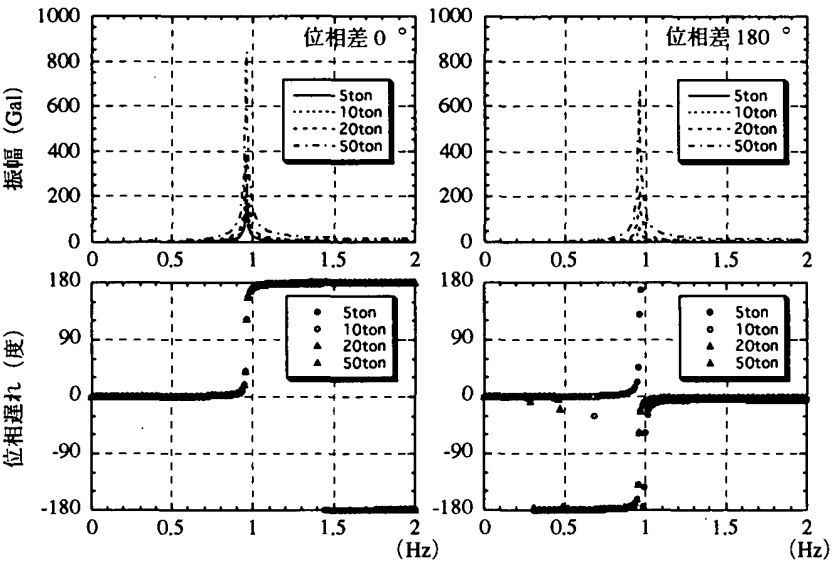

(b) 頂部応答

図 12 地動と頂部の正弦波入力による結果（位相差 $0^{\circ} 、 180^{\circ}$ ）
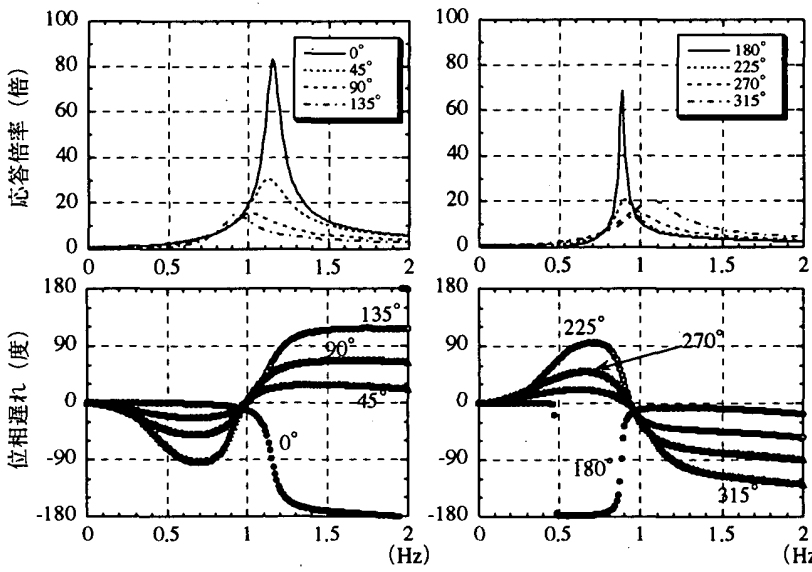

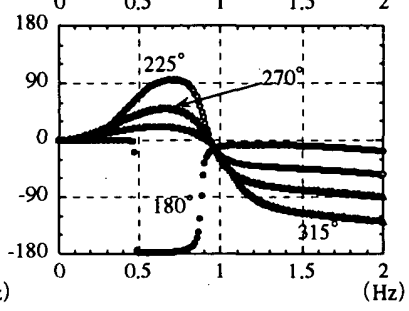

(a) 伝達関数
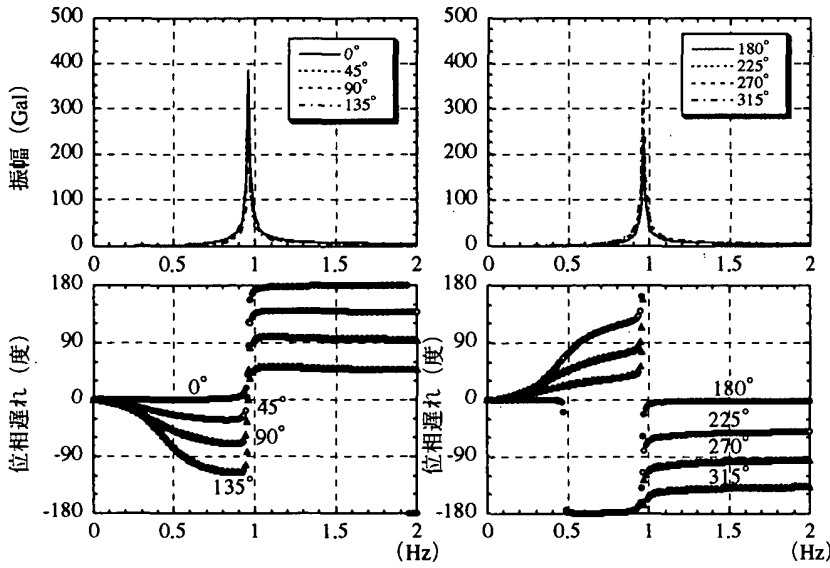

(b) 頂部応答

図 13 地動と頂部の正弦波入力による結果（上部入力 20tonf） 

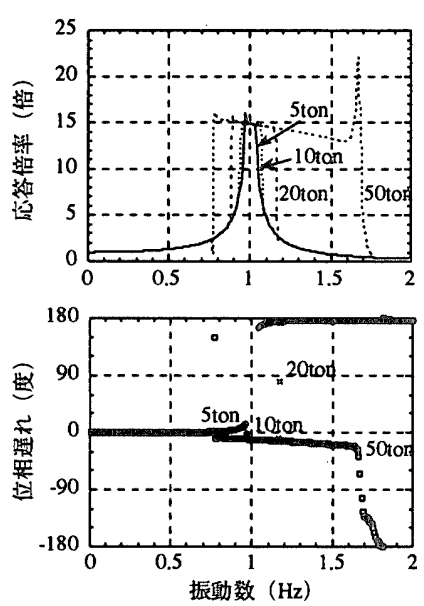

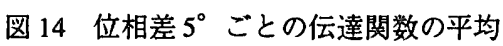

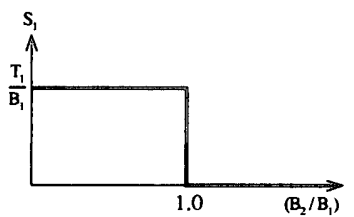

(a) $\mathrm{S}_{1}$

$\overrightarrow{B_{2}\left(B_{1}\right)}$

図 $16 \mathrm{~B}_{1}, \mathrm{~B}_{2}$ の大小による積分結果

次に、上部入力 5〜 50tonの各ケースに関し、地動と上部入力の

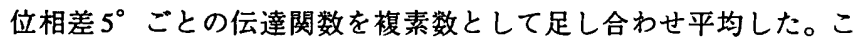
の平均操作は、ある面で実測結果のデー夕解析の過程と類似性を有

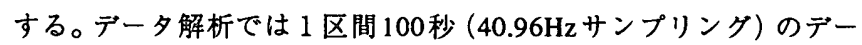
夕を 36 区間用いアンサンブル平均を行っている。4).5) ノイズと信号 の独立性等を前提としている訳であるが、別の面から見れば有限区 間長・有限区間数の平均を計算しているにすぎないとの見方も可能 であり、区間ごとに上部・地動入力間の位相差は当然異なっている 事から、本章で行った平均の計算と、デー夕解析における平均の計 算に類似性があると言える。

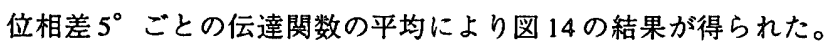
この図から以下が言える。

上部入力の存在によりピークの幅が広がる。その程度は、上部 入力が大きい程顕著である。広がり方は左右均等ではなく、やや 高振動数側に片寄っている。

ピークの高さは、上部入力の大きさによらずほほ一定である。 ピーク付近では位相は $0^{\circ}$ 付近から $-180^{\circ}$ 一も変化する。位相 が変化する振動数は、ピークの高振動数側の端部付近である。

実測結果との共通点としては、上部入力が大きくなるとピーク の幅が広がる点、位相が $0^{\circ}$ 付近から $-180^{\circ}$ 人も変化する点、位 相変化の振動数が基礎固定時の共振振動数より高振動数側に変わ る点、これらの現象が上部入力が大きいほど顕著である点、等が あげられる。

さらに、図14の応答倍率において、低振動数側からある振動数ま では下部入力のみの場合の伝達関数上にあり、ある振動数範囲で上 部入力のみの場合の伝達関数上に移動した後、再び下部入力伝達関 数上に戻るように見える点に着目し、また伝達関数の平均でなく実 測のデー夕解析と同様のパワースペクトル・クロススペクトルに相 当する量の平均を求めた後に比をとって得た伝達関数はどうなるか
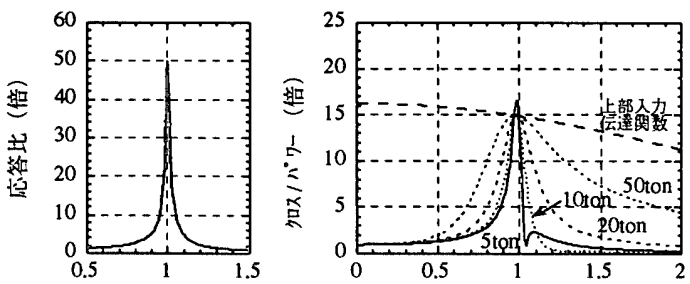

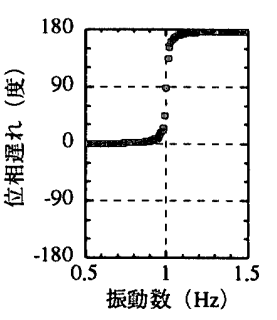

(b) 下部入力時伝達関数

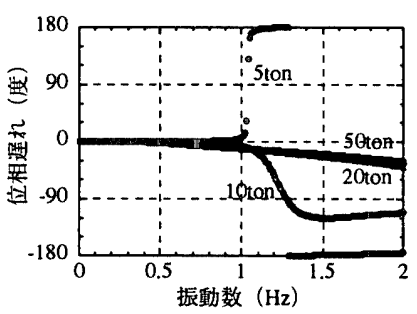

(c) クロス/パワー
図 15 異なる方法で求めた伝達関数の比較

を確認するため、図 15 に、(a)図 14 に上部入力時の振幅を加えたも の、(b)下部入力時、(c) 上部・下部入力時応答の（クロススペクトル／ パワースペクトル）を示した。これから以下が言える。

・伝達関数をとってから平均した場合の応答倍率は、下部入力時 ピークのやや低い振動数までは下部入力時伝達関数上にあった後 に上部入力時伝達関数上にジャンプし、下部入力時ピークのやや 高い振動数で再び下部入力時伝達関数上に戻る。

・クロス/パワーによる伝達関数は、上部入力が大きいほど幅が 広い点、ピーク高さが上部入力のみの場合とほほ一致している点 など、伝達関数を平均したものとの類似点がある。また上部入力 が大きい程幅が広い現象は、実測結果と極めて類似している。 上記現象のメカニズムは、数学的に以下のように説明し得る。

(1) 伝達関数の平均の場合

ある振動数に招ける平均 $\mathrm{S}$ は、無限個の平均として位相差 $\theta$ が 0 から $2 \pi$ までの積分を考えると下記(2)式で表す事ができる。

$$
\begin{aligned}
S & =\frac{1}{2 \pi} \int_{0}^{2 \pi} \frac{\mathrm{T}_{\mathrm{e}} \mathrm{e}^{\mathrm{i} \theta}+\mathrm{T}_{2}}{\mathrm{~B}_{1} \mathrm{e}^{\mathrm{i} \theta}+\mathrm{B}_{2}} \mathrm{d \theta} \\
& =\frac{1}{2 \pi} \int_{0}^{2 \pi} \frac{\mathrm{T}_{1}}{\mathrm{~B}_{1}+\mathrm{B}_{2} \mathrm{e}^{-\mathrm{i} \theta}} \mathrm{d} \theta+\frac{1}{2 \pi} \int_{0}^{2 \pi} \frac{\mathrm{T}_{2}}{\mathrm{~B}_{1} \mathrm{e}^{\mathrm{i} \theta}+\mathrm{B}_{2}} \mathrm{~d} \theta
\end{aligned}
$$

ここで $\mathrm{T}_{1}$ : 上部入力時頂部応答（複素数、以下同）

$$
\begin{aligned}
& T_{2} \text { : 下部入力時頂部応答 } \\
& B_{1} \text { : 上部入力時下部応答 } \\
& B_{2} \text { : 下部入力時下部応答 }
\end{aligned}
$$

(2)式の積分は複素変数の積分に変換でき、(2)式第 1 項を $\mathrm{S}_{1} 、$ 第 2 項を $S_{2}$ とすると $S_{1}$ 刘 $B_{1}||_{2} \mid$ の大小により以下のように求まる。

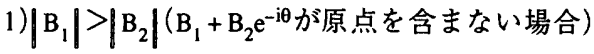

$$
\begin{aligned}
\mathrm{B}_{1} & +\mathrm{B}_{2} \mathrm{e}^{-\mathrm{i} \theta}=\zeta \text { とおくとd } \frac{1}{2 \pi} \int_{0}^{2 \pi} \frac{\mathrm{T}_{1} \mathrm{~d} \theta}{\mathrm{B}_{1}+\mathrm{B}_{2} \mathrm{e}^{-\mathrm{i} \theta}}=\frac{1}{2 \pi} \oint_{\gamma} \frac{\mathrm{d} \zeta / \mathrm{B}_{2}(\sin \theta+\mathrm{i} \cos \theta) よ り}{\mathrm{~B}_{2}(\sin \theta+\mathrm{i} \cos \theta) \zeta} \\
& =\frac{1}{2 \pi} \oint_{\gamma} \frac{\mathrm{T}_{1} \mathrm{~d} \zeta}{\mathrm{ie}^{-\mathrm{i} \theta} \mathrm{B}_{2} \zeta}=\frac{1}{2 \pi} \oint_{\gamma} \frac{\mathrm{T}_{1} \mathrm{~d} \zeta}{\mathrm{i}\left(\zeta-\mathrm{B}_{1}\right) \zeta} \\
& =\frac{1}{2 \pi} \cdot 2 \pi \mathrm{i} \frac{\mathrm{T}_{1}}{\mathrm{iB}_{1}}=\frac{\mathrm{T}_{1}}{\mathrm{~B}_{1}}
\end{aligned}
$$




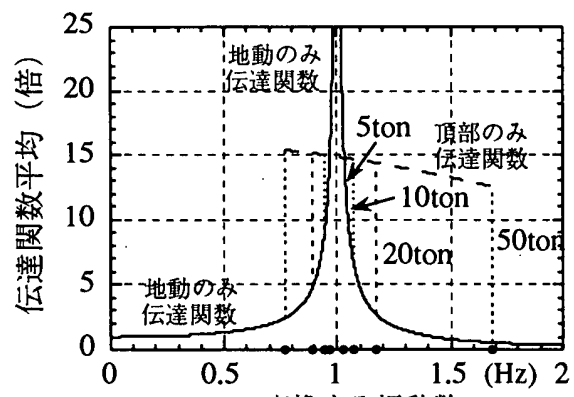

(a) 変換する振動数

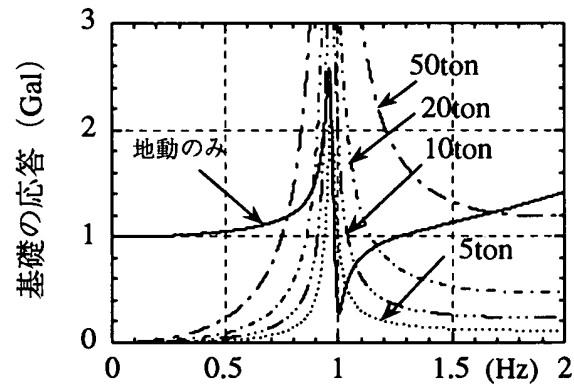

(b) 基礎の動き

困 17 基礎の動きの大小関係の変換する振動数と基礎の動き

上記の最後の部分は、 $\mathrm{f}(\zeta)=\mathrm{T}_{1} / \mathrm{i} \zeta$ とてコーシーの積分表示 $f(\alpha)=\frac{1}{2 \pi \mathrm{i}} \oint_{\mathrm{c}} \frac{\mathrm{f}(\mathrm{z})}{\mathrm{z}-\alpha} \mathrm{dz}$ を用いた事による。

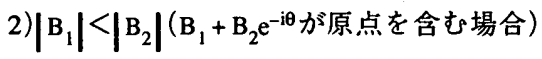

上記と同様の計算により、また積分が留数の和で表される事から

$\mathrm{S}_{1}=\frac{1}{2 \pi} \cdot 2 \pi \mathrm{i} \cdot \frac{\mathrm{T}_{1}}{\mathrm{i} \mathrm{B}_{1}}+\frac{1}{2 \pi} \cdot 2 \pi \mathrm{i} \cdot \frac{\mathrm{T}_{1}}{\mathrm{i}\left(-\mathrm{B}_{1}\right)}=0$

$\mathrm{S}_{2}$ に関しても同様の計算を行うと、 $\left|\mathrm{B}_{1}\right|>\left|\mathrm{B}_{2}\right|$ の場合 $\mathrm{S}_{2}=0,\left|\mathrm{~B}_{1}\right|<$ $\left|\mathrm{B}_{2}\right|$ の場合 $\mathrm{S}_{2}=\mathrm{T}_{2} / \mathrm{B}_{2}$ が得られ、これらを図示すると結局図 16 が得ら れた。また図 14 に関し $B_{1} 、 B_{2}$ に相当する量を求め、これらの大小 関係が変換する振動数を图示すると図 17 となる。

（2）（クロススペクトルの平均）／(パワースペクトルの平均）の 場合

この場合も、ある振動数における值 $\mathbf{S}^{\prime}$ は、上記と同様に考え下式 で与えられる。この式からは、上記のような簡明な結論を数学的に 導く事は困難である。

$$
S^{\prime}=\frac{\int_{0}^{2 \pi}\left(T_{1} e^{i \theta}+T_{2}\right)\left(B_{1} e^{i \theta}+B_{2}\right)^{*} d \theta}{\int_{0}^{2 \pi}\left|\left(B_{1} e^{i \theta}+B_{2}\right)\right|^{2} d \theta}
$$

以上、(1)、(2)の検討から、以下が言える。

伝達関数の平均に見られる現象は数学的に説明可能である。下 部入力による基礎の動きが上部入力による動きより大きい場合に は下部入力時伝達関数と等しく、逆の場合には上部入力時の伝達 関数と等しい。なお図15に見られる理論値との差は、連続関数の 積分でなく $5^{\circ}$ きざみの平均をとった事によると考えられる。ま た 2 入力間の位相差が $0 \sim 2 \pi$ の間で均等に分布すると仮定し位 相差に関する積分 (平均) が数学的操作の中で重要であった事か ら、位相差の分布状態が現象の発生に重要な役割を果たす事が分
かったと言える。

・クロスノパワーに見られる現象は、現段階では数学的に簡明な 説明ができない。

・個々のデータ区間で伝详関数をとってから平均し推定精度を上 げる方法も、それぞれ平均した後にクロス/パワー等を求める方 法に類似のものとして、従来行われてきた。ここでは前者に関連 するケースについては簡明な数学的説明ができた。後者に関して も、方法の類似性から間接的には数学的に説明し得たとも考えら れるが、直接、数学的にも説明することは今後の課題と言える。

\section{4. 上部入カと地動の独立ランダム 2 入カが存在する系の伝達関数}

独立な 2 入力があるとき地動入力のみの場合と比較し伝達関数の ピークが広がり位相も変化する現象がシミュレーションで再現され る事は、筆者らの既報4) や飛田8) らにより確認されている。ここで は、前章と同じ 1質点系モデルを用いて本論内での条件を統一し、 上部と地動に独立ランダム 2 入力を与えた場合を検討する。ランダ 厶波は $0 \mathrm{~Hz} \sim 20 \mathrm{~Hz}$ で一定のパワーを持ち、rms 值で振幅を規定す る。振幅としては地動が 1Gal、上部の加振力が 5tonf、20tonf とし た。また実測と同様 100 秒 $\times 36$ 区間の応答結果のアンサンブル平均 により伝達関数を求めた。実測結果（因 4 と同一）、19質点スウェ イ・ロッキングばね付シミュレーションモデルによる結果4).5) と共 に、結果を図 $18 \sim 20$ に示した。これらから以下の事が言える。 上部と地動に独立 2 入力を与えると、1 質点系モデルでも実測や シミュレーションモデルの結果と非常に類似の結果が得られた。

従って、上下独立 2 入力は、強風時に伝達関数のピークが広が りまた位相の様子も変わるなど形状が変化し、見かけの減衰定数 が大きくなる現象に大きく関与していると言える。

なな㧍、上記の図 14 に関する検討で論じた点に注意すると、独立 な 2 入力として設定した現象の性質のうち、2 入力の同じ振動数 成分間の位相差が時間により異なる、すなわち応答解析を行った 36区間でそれぞれ異なる点が重要であると言える。実測結果にお いても、ランダムな現象であるため、アンサンブル平均の各区間 で位相差は異なっていると考える事ができる。

、図18〜20の現象は図 15(c) と類似である。これは、クロス/パ ワーとして計算している点で共通性がある。

上部入力の大きさに関しては以下のように考えられる。图19の 実測に打ける、風速 $1.5 \mathrm{~m} / \mathrm{s}$ 時と風速 $13.2 \mathrm{~m} / \mathrm{s}$ 時の建物頂部振幅 $\mathrm{rms}$ 值の比は約 $6\left(4.2 \mu \mathrm{m}: 25.4 \mu \mathrm{m}^{4}\right)$ である。一方図 18 の 20tonf は 地動入力による慣性力の約 4 倍（表 1 参照）となっている。この 事から、図18の解析と図 19 の実測の 2 入力の大きさの比は、や や差があるもののほほ等しいと言える。

\section{5. 結論}

本論の検討により以下の結論が得られた。

1) 上部・下部入力が存在し両者間の位相差が $0 \sim 2 \pi$ 間で均等に 分布する時、パワースペクトルとクロススペクトルのアンサンブ ル平均の比をとって伝達関数とする、観測デー夕に対する处理法 と同様の処理を行うと、実測の伝達関数と類似の現象が解析結果 で見られた。またこの手法と類似な、伝達関数の平均をとる処理 

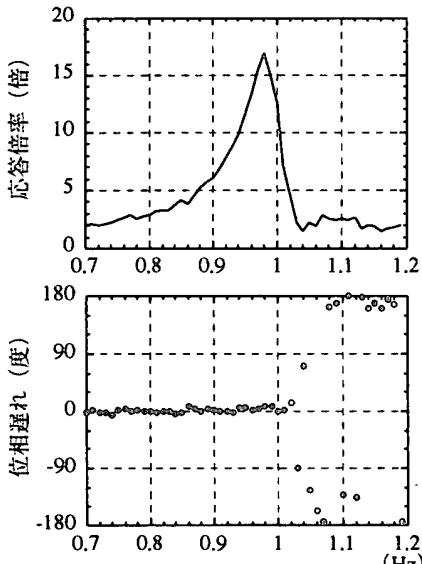

(a) 上部入力 5 tonf
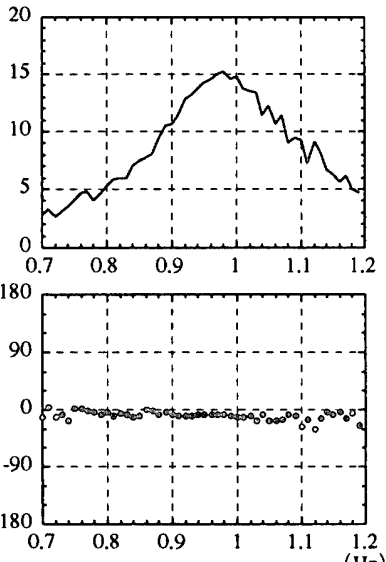

(b) 上部入力 20 tonf

図 18 独立ランダム 2 入力による伝達関数
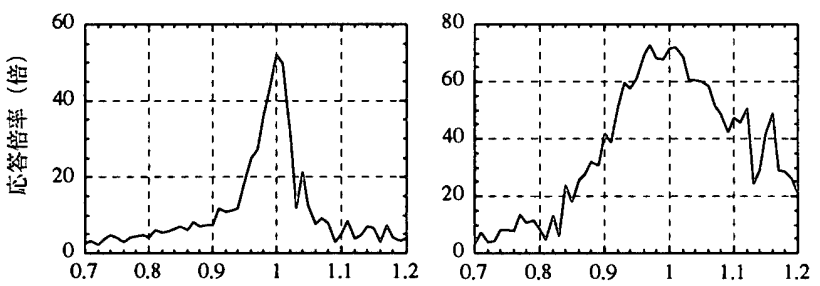

(a) 風速 $1.5 \mathrm{~m} / \mathrm{s}$

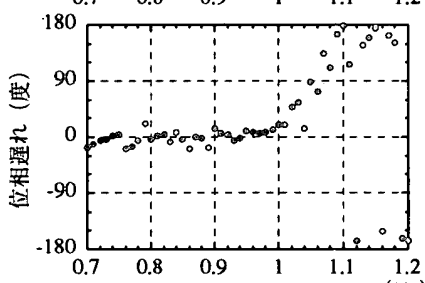

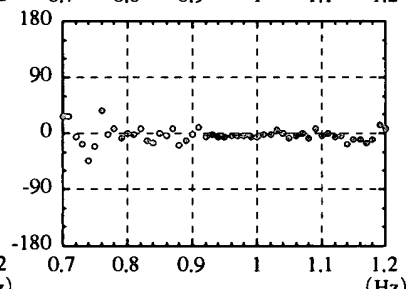

(b) 風速 $13.2 \mathrm{~m} / \mathrm{s}$
図 19 実測結果による伝達関数

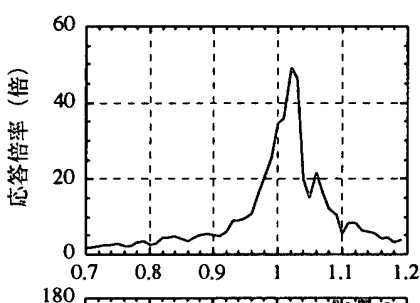

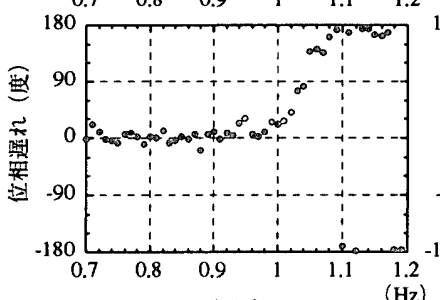

(a) 風速 $5 \mathrm{~m} / \mathrm{s}$

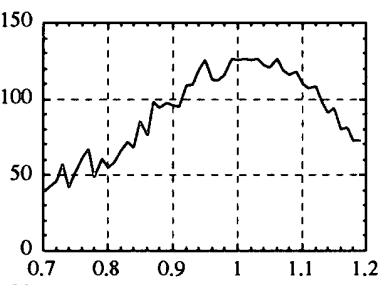

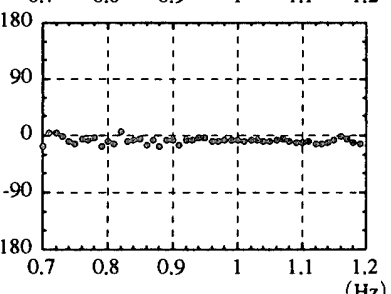

(b) 風速 $15 \mathrm{~m} / \mathrm{s}$
図 2019 質点シミュレーション結果による伝達関数

によっても、実測の伝達関数と類似の現象が見られた。

2）伝達関数の平均をとる場合には、位相差に関する平均により実 測と類似の現象が現れる事を数学的に示した。またこの際、上部 入力のみの場合の伝達関数が、見かけ上変化した伝達関数の頂部 付近の值になる事、さらに、伝達関数の見かけ上の変化には $2 つ$ の入力それぞれに対する基礎の応答の大小関係が重要で、下部入 力に対する基礎の応答が大きい場合には下部入力のみの場合の伝
達関数と一致し、上部入力に対する基礎の応答が大きい場合には 上部入力のみの場合の伝達関数と一致する事が分かった。

3）これらの事から、風外力が存在し伝達関数が見かけ上変化する 現象に関し、伝達関数を平均する場合については現象のメカニズ ムを数学的に示したと言える。

4) また 2 入力が位相差を持った正弦波である場合の伝達関数が位 相差によりどう変化するかや、上部入力のみの場合の複数のモデ ルに関する伝達関数も調べた。その結果これらの場合において も、伝達関数の変化に関し実測結果と類似の傾向が見られた。位 相差に関し平均した場合の上記の結果と総合し、これらは、上部 入力の存在により伝達関数が見かけ上変化するメカニズムに関す る理解を助ける知見と言える。

5) 以上本論の検討により、上部入力の存在で伝達関数が見かけ上 変化する際の、発生する現象と諸因子との関連が示され、またあ る部分に関してはその理由が数学的に明らかになった。今後、許 容誤差の観点から、上部と下部入力の比を指標とし、一般的な建 物に関する適用限界を定量的に求める予定である。

\section{参桴文献}

1) Luco, J. E.: Linear Soil-Structure Interaction, Report UCRL-15272, Lawrence Livermore National Laboratory, 1980.

2 ）佐藤耕司，内藤幸雄，内山正次，前田達哉，增田潔：基礎が変形しロッ キングする構造物の振動特性推定法、鹿島技術研究所年報第 43 号、pp. $143 \sim 148,1995.12$

3）田村幸雄, 佐々木淳, 塚越治夫: ランタムな外力による強制振動時の減 衰評価ーバフェッティング振動時の減衰定数について、日本風工学会 誌、第 47 号、pp. 93 94、1991. 4

4) 石橋敏久, 内藤幸雄：常時微動による高層構造物の振動特性推定に及ほ す風の影響の検討、日本建筑学会構造系論文集、第 464 号、pp. 71～80、 1994. 10

5）石橋敏久，内藤幸雄，横山和人：常時微動に上る構造物の振動特性推定 に及はす風の影響（その1）、鹿島技術研究所年報、第40号、pp.137 142、1992. 10

6）内藤幸雄, 石橋敏久, 横山和人：常時微動に上る構造物の振動特性推定 に及はす風の影響（その 2 ）、鹿島技術研究所年報、第 40 号、pp. 143 146、1992. 10

7）山谷博愛，内藤幸雄，石橋敏久：地盤・構造物相互作用が棈造物の振動 特性推定に及はす影響、鹿鳥技術研究所年報、第 42 号、pp. 169 174、 1994. 10

8）飛田潤:実応答記録に基づく建築構造物の振動システムの特性に関する 研究、東北大学学位論文、1989. 1

（1996年10月 9 日原稿受理，1997年 2 月25日採用決定） 